\title{
Nigerian Universities Outputs and Their Employability in the Labour Markets in South- South, Nigeria
}

\author{
Asuquo Austin Effiong*, Agboola Bolapeju Mary \\ Department of Curriculum Studies, Education Management and Planning, University of Uyo, Uyo, Akwa Ibom State \\ *Corresponding author: timstat@yahoo.com
}

Received October 09, 2014; Revised November 14, 2014; Accepted December 24, 2014

\begin{abstract}
This study examines Nigerian Universities outputs and their employability in the labour market in South-South, Nigeria. The descriptive design of expost facto type was used and the study population comprised Nigerian Universities graduates in both private and public establishments in South-South, Nigeria. Researcher developed questionnaire tagged "Universities Outputs and their Employability Questionnaire" which was validated by two independent experts in Test and Measurement and was used in data collection. Reliability of this instrument was tested and Cronbach alpha reliability coefficient of 0.89 was obtained. Multi-stage sampling was used to select sample of 1200 UNiversities graduates, 600 from private and 600 from public establishments in South-South, Nigeria. Frequencies and percentages were used to analyse the demographics of these employers while both one sample t-test and independent t-test were used to test research hypotheses at 0.05 level of significant. The Statistical Package for Social Sciences (SPSS version 20.0) was used to enhance data analysis. Result showed that the employability of Nigerian Universities outputs based on the responses of their employers who rated them was significantly below average. This result was indifference in spite of differences respondents' sex, organisation type, educational qualification and age. Hence, management of University education in Nigeria should collaborate with the employers of labour in designing the university curriculum. Also, a more robust and proactive steps should be taken by Nigerian government to improve the existing industrial training programme and other programme channeled towards enhancing the employability of Universities outputs in South- South and in Nigeria at large.
\end{abstract}

Keywords: graduate employability, university outputs, unemployment

Cite This Article: Asuquo Austin Effiong, and Agboola Bolapeju Mary, "Nigerian Universities Outputs and Their Employability in the Labour Markets in South- South, Nigeria.” American Journal of Educational Research, vol. 2, no. 12 (2014): 1244-1249. doi: 10.12691/education-2-12-18.

\section{Introduction}

General approaches to quality education are essential for national and regional developments are undergoing major changes. In 2000 for instance, the United Nations Solemnly reaffirmed the international development goals and as a result, the priority attached to a concerted fight for quality education has on a new dimension. The last two decades have witnessed vast changes in education system everywhere and in the type and quality of education they offer. In developing countries, for instance, quality education for all has fully become a reality changes in the social and economic structures of society and curriculum reforms seems to have had a little influence on education. The provision of quality education in developing economic, especially in Nigeria, is more of a myth than a reality (Ifinedo \& Ololube, 2007). It has been affirmed that Nigeria is facing a great number of complex challenges despite her great opportunities and assets in terms of materials and human resources (Ololube, 2006).

Quality education through an improved curriculum would in no doubt give millions of recipient skills to rise out of poverty, improve their status, mobility and decision making which will in turn propel national and regional development while its failure may likely result to social, political and economic crises in the nearest future. Education generally in Nigeria has been neglected with University education been the worst hit by successive governments in terms of effective management, quality control and provision of adequate quality resources for effective teachning and learning. Although, reasonable efforts have been made to improve the quality of Universities education in the past one decade, yet with all these efforts, it appears little success has been achieved. The goals of University education remains elusive and seems unachievable as the universities products(graduates) in Nigeria often time could not marry knowledge acquired in schools with that of the labour market (Olofintoye, \& Prince, 2013). Moreover, majority of graduates who are degree holders (Bachelor, Masters and Doctorates Degree holders) remain unemployed and for those employed, there are allegations by their employers, that most Nigeria University graduates lack job related skills and perform below expectation.

The former education minister, Sam Egu, when speaking at a retreat for the newly reconstituted governing council boards for federal universities in Abuja attributed 
this ugly trend to poor teaching in the system, inadequate and obsolete infrastructure and equipment as well as poor library facilities. On the low quality of graduates, he said about 15-30 percent of the instructional and infrastructural facilities are non-functional, obsolete or dilapidated. This has a clear adverse consequence on the quality of teaching, learning and research as only $20 \%$ of graduate from Nigeria universities are employable in other words, 80\% of Nigerian graduates lack requisite skills for employment. The instructional processes in our Universities have lost their rigor as many institutions could not function well. The adduced reasons for this problem include insufficient fund, incompetent and inadequate staff to carry out quality teaching reduce to various factors such as insufficient finance, lack of fund incompetent factor staff to carry out teaching quality (Ololube \& Egbezor, 2009; Ololube, Egbezor \& Kpolovie, 2008).

\subsection{Statement of the Problem}

In recent times, high rate of unemployment among youths, poor school facilities, high examination failure rate, lack of skilled manpower, inadequate school equipments, decayed infrastructure coupled with the increase in the school enrolment rate are some of the problems that is still prevalent problems in Nigeria (Olaleye, 2009). In Nigeria up to date, many intending students who want to secure admission into Universities could not because of the large number of students seeking admission. In an effort to address this problem, the federal government established new federal universities. The introduction of these new Universities has increased the number of graduates in Nigeria which have also increased the already exiting high rate of unemployment in the country as so many graduates could not secure reasonable employment (Olofintoye \& Prince, 2013).

Although, governments have initiated many programmes to alleviate this problem but the problem still remains unabated as unemployment rate is still very high in Nigeria. Could it be that these universities outputs are not employable? It is line with this that this study examines Universities outputs and their employability in the labour market in South- South, Nigeria.

\subsection{Concept of Employability}

Employability refers to the capability to gain and maintain employment (Hind \& Moss, 2011). The employability of an individual depends on the knowledge, skills and abilities an individual possesses. Employability can also be defined as a person's capability of gaining initial employment, maintaining employment and obtaining new employment if required (Hillage and Pollard, 1998). In simple terms, employability is about being capable of getting and keeping fulfilling work. Also, employability is the capability to move self-sufficiently within the labour market to realize potential through sustainable employment. In the word of Overtoon (2000) employability means, "having essential functional and enabling knowledge, skills and attitudes required by the millennium workplace, necessary for career success for all levels of education”.

Employability skills which are skills necessary for getting, keeping and doing well on a job are very important for all employees to be an asset to the labour market. These skills include attitudes, and actions that enable workers to get along with their fellow workers and supervisors and to make sound, critical decisions (Brown \& Hesketh, 2004). While most people view employability in absolute terms, focusing on the need for individuals to obtain credentials, knowledge and social status; the concept of employability can also be seen as subjective and dependent on contextual factors. Employability not only depends on whether one is able to fulfill the requirements of specific jobs, but also on how one stands relative to others within a hierarchy of job seekers (Brown and Hesketh,2004).

\subsection{Theoretical Framework}

The theoretical framework of this study can be explained by the Human Capital theory. This theory according to Schultz (1963) emphasizes the role of investment in education to boost economic and social achievement.

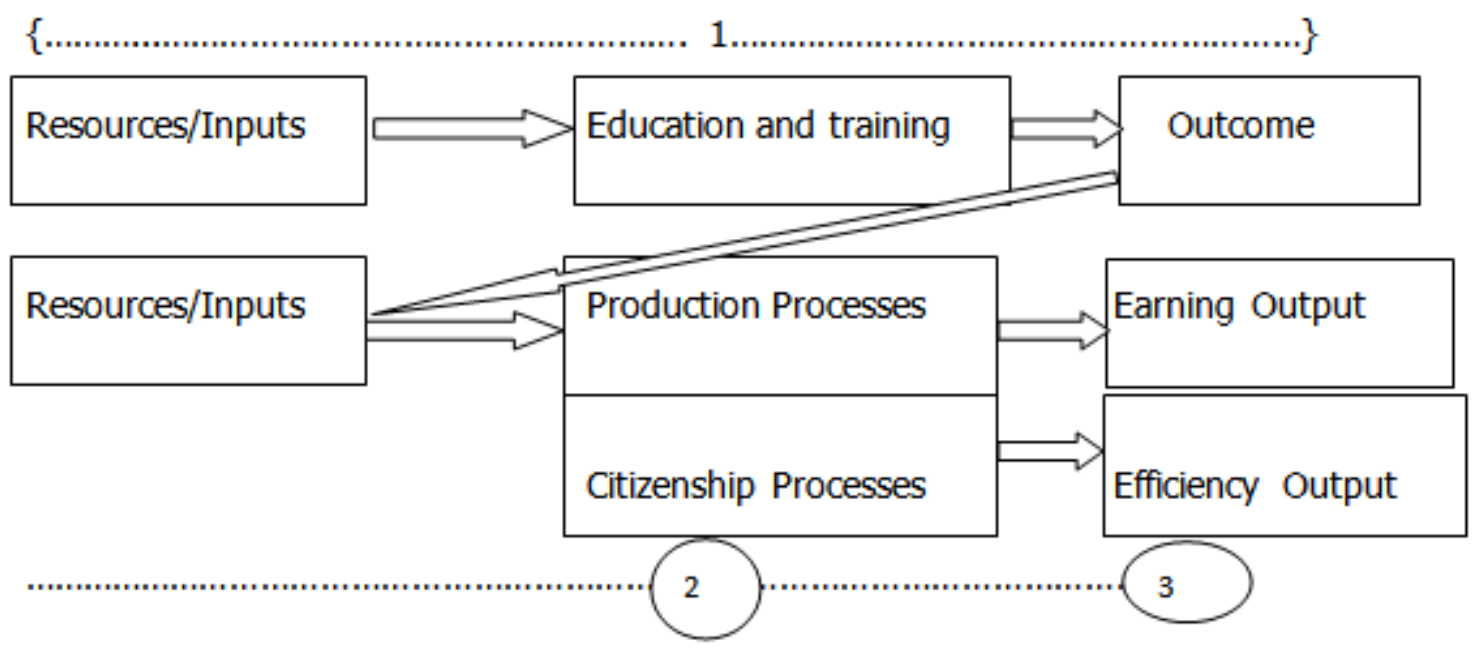

Figure 1. A model of Human Capital Theory (Swanson, 2001)

The diagrammatic representation of the human capital theory above presents the key relations in human capital theory. The first relationship 1 represents the concept of production as applied in education and training. This relationship means that investment in education and training results in increased learning (Imeokparia \& Ediagbonya, 2012). The relationship 2 presents the relationship between learning and increased productivity. 
This means that increased learning can result to an increased productivity. This relationship emphasizes the human capital relationship that exists between increased productivity and increased wages and business learning. This relationship 3 pointed out that an increased productivity does result in increased waged for individuals. The human capital theory is a replicate of the human resource development theory which play emphasize on the investment in the training and development of human resources, therefore according to human capital theory, it can be concluded that when adequate resources are committed to the development of human capital which is the stock of competencies, knowledge, habit, social and personality attributes of the society, the nation will witness growth and development. This theory is of relevance because when governments at all level are committed to the development of human capital through provision of qualitative education, the employability of Nigerian universities output will improve.

\section{Objectives of the Study}

1. To assess the employability of Nigerian Universities outputs in South-South Nigeria.

2. To examine the differences in the employability of male and female Universities outputs in the labour markets in South-South, Nigeria.

3. To examine the differences in the employability of Universities outputs in private and public establishments in South-South, Nigeria.

4. To examine the differences in the employability of Universities Outputs in the labour markets in SouthSouth who have first degree and those with postgraduate degrees.

\section{Research Hypotheses}

1. The employability of Nigerian Universities outputs in South-South Nigeria is not significantly below standard.

2. There is no significant difference in the employability of male and female Universities outputs in the labour markets in South-South, Nigeria.

3. There is no significant difference in the employability of Universities outputs between graduates in private and public establishments in South-South, Nigeria.

4. There is no significant difference in the employability of Universities outputs in the labour markets in South-South between graduates who have first degree and those who have postgraduate degrees.

\section{Methodology}

The area of this study is the South-South; Geo-political Zone of Nigerian Comprising Akwa Ibom, Bayelsa, Rivers, Cross-River, Delta and Edo State.The design of this study is expost facto descriptive design. This design was used to assess the employability of Nigerian Universities outputs in South-South, Nigeria. This design was considered appropriate for this study because data were collected after the event had taken place and also research variables were manipulated but are measured as they occurred. Universities outputs who are Universities graduates in both private and public organizations in the six states in South-South, Nigeria made up the population of this study. Multi-stage sampling was used to select 1200 graduates in the labour market in the study area. At the first stage of sampling, simple random sampling was used to select sample of four states from the six states in this zone. Then, at the second stage, state capital of each of the selected states were selected purposively and then sample of 300 graduates 150 from private organization and 150 from public organization were selected.

Researcher constructed questionnaire tagged Universities Output and Employability Questionnaire UQAEA which was validated by two experts in Test and Mesayrement and thereafter tested for reliability was used in data collection. The instrument comprised two major sections; section A captured the demographics of the employers while section B assesses the employability of Nigeria Universities outputs. The total number of items on the scale is 24 items and Cronbach Alpha reliability coefficent of 0.89 was obtained. All items on section B were rated on four points Likert scale of strongly agree (4 points), agree (3 points) disagree (2 points) and strongly disagree (1 point). The demographic part of the questionnaire was filled by the respondents while top management staff in these organizations which include Managing Directors, Managers and Directors of various organisations where these graduates work were assessed the employability of their surbondinates.

The researcher visited the respondents in their various offices and then the instrument was administered. Four research assistances were also deployed who assisted to facilate the administration of the instrument and of the total 1200 copies of the questionnaire administered, 1183 useable copies were retrieved. Frequencies and percentages were used to analyze the demographic of the respondents while the one- sample $t$-test and independent were used to test research hypotheses. All research hypotheses were tested at the 0.05 level of significance. To enhance data analysis, the statistical package for social science (SPSS version 20.0) was used.

\section{Results}

Table 1. Demographics of the Respondents

\begin{tabular}{lll}
\hline \multicolumn{3}{c}{ Table 1. Demographics of the Respondents } \\
\hline Sex & No. of Respondent & Percentage (\%) \\
Male & 695 & 58.7 \\
Female & 489 & 41.3 \\
Total & 1184 & 100.0 \\
Type of organization & & \\
Private & 595 & 50.3 \\
Public & 589 & 49.7 \\
Total & 1184 & 100.0 \\
Age(years) & & \\
20 - 30 & 659 & 55.7 \\
Above 30 & 525 & 44.7 \\
Total & 1184 & 100.0 \\
Educational Qualification & & \\
First Degree & 696 & 58.8 \\
Postgraduate Degree & 488 & 41.2 \\
Total & 1184 & 100.0 \\
\hline
\end{tabular}


Result in Table 1 showed the distribution of the demographics of the respondents. The result revealed that 695(58.7\%) were male and 489(41.3\%) were female. Also, $50.3 \%$ of the respondents work in private organisations while $49.7 \%$ work in public establishments. The result of the distribution of the respondents' age showed that 55.7\% of the respondents were young adult (20- 45 years) and $44.3 \%$ were old adults (above 45 years). Result also showed that $58.8 \%$ were first degree holders while $41.2 \%$ were postgraduate Degree holders.

\subsection{Hypothesis One}

Ho$_{1}$ : The employability of Nigerian Universities outputs in South-South Nigeria is not below standard based on the rating of employers of labour in South South, Nigeria.

Table 2. One sample t-test Analysis of the employability of Nigerian Universities outputs in the labour market in South-South, Nigerian as rated by the employers of labour

\begin{tabular}{cccccc}
\hline Variables & $\bar{X}$ & SD & Weighted mean & Theorectical Mean & tcalc. \\
\hline Employability of universities & 32.63 & 10.43 & 1.78 & $2.50 \quad-1.96$ & Rejected
\end{tabular}

$\mathrm{N}=1184, \mathrm{df}=1183, \mathrm{p}<0.05$, significant at 0.05 .

The employers rating of the employability of universities outputs in the Labour Market in South-South, Nigeria based on their weighted scores were compared with the expected weighted mean of 2.50 which is the expected mean for a four point likert scale. The result showed that their wieghted mean is significantly less than expected weighted mean $(\mathrm{p}<0.05)$. The weighted mean obtained is significantly less than the theorectic mean

which means that the employability of universities outputs in the labour market in South-South, Nigeria is below average.

\subsection{Hypothesis Two}

$\mathbf{H o}_{2}$ : There is no significant difference in the employability of male and female Universities outputs in the labour markets in South-South.

Table 3. t-test Analysis of the differences in the Employability of male and female Universities Outputs in South-South, Nigeria

\begin{tabular}{cccccc}
\hline Sex & N & $\bar{X}$ & SD & tcalc. & Remark \\
\hline Male & 695 & 35.22 & 10.55 & -1.62 & -1.96 \\
Female & 489 & 36.22 & 10.47
\end{tabular}

$\mathrm{N}=1184, \mathrm{df}=1182, \mathrm{p}<0.05$, not significantly different.

Result in Table 3 showed an insignificance difference in the employability of male and female Universities Outputs in South-South, Nigeria. The t calculated (-1.62) is not greater than the $t$ critical $(-1.96)$ at the 0.05 level of significance with 1182 degree of freedom. Therefore, it is concluded that there is no significant difference in the

employability of male and female universities outputs by in South-South, Nigeria.

\subsection{Hypothesis Three}

$\mathbf{H o}_{3}$ : There is no significance difference in the employability of Universities outputs in private and public organisations in South-South, Nigeria.

Table 4. t-test Analysis of the Differences in the Employability of Universities in Private and Public Establishments in South-South, Nigeria

\begin{tabular}{|c|c|c|c|c|c|c|}
\hline Types of Organization & $\mathrm{N}$ & $\bar{X}$ & SD & tcalc. & tcrit. & Remarks \\
\hline \multirow[t]{2}{*}{ Private } & 595 & 35.20 & 10.53 & -1.43 & -1.96 & \\
\hline & & & & & & Not rejected \\
\hline Public & 589 & 36.07 & 10.52 & & & \\
\hline
\end{tabular}

\footnotetext{
$\mathrm{N}=1184, \mathrm{df}=1182, \mathrm{p}>0.05$, not significantly different.

Results presented in Table 4 revealed an insignificant difference in the employability of Nigerian Universities between graduates in private and public organisations in South-South, Nigeria. The t calculated value of -1.43 was obtained which is not greater than its corresponding $t$ critical value of -1.96 at 0.05 level of significance. Hence, there is no signifcant difference in the employability of
}

Nigerian Universities between graduates in private and public organisation in South-South, Nigeria.

\subsection{Hypothesis Four}

$\mathrm{HO}_{4}$ : There is no significant difference between in the employability of graduates who had first degree and those with postgraduate degrees in South-South, Nigeria. 
Table 5. $t$ test Analysis showing differences in the Employability of Universities graduates who had first degree and those with postgraduate degrees in South-South, Nigeria

\begin{tabular}{|c|c|c|c|c|c|c|}
\hline Academic Qualification & $\mathrm{N}$ & $\bar{X}$ & SD & tcalc. & tcrit. & Remarks \\
\hline \multirow[t]{2}{*}{ First Degree } & 696 & 35.24 & 10.55 & -1.56 & -1.96 & \\
\hline & & & & & & Not rejected \\
\hline Postgraduate Degree & 488 & 36.20 & 10.48 & & & \\
\hline
\end{tabular}

$\mathrm{N}=1184, \mathrm{df}=1182$, not significantly $0.05(\mathrm{p}>0.05)$.

Result in Table 5 showed that the calculated $\mathrm{t}(-1.56)$ is not greater than the $t$ critical (-1-96) at 0.05 level of significance with 1182 degrees of freedom. Therefore, there is no significant difference between in the employability of graduates who had first degree and those with postgraduate degrees in South-South, Nigeria.

\section{Discussions of Findings}

This study examined the employability of Nigerian Universities Outputs in the Labour markers in SouthSouth, Nigeria. The finding revealed that the employability of Nigerian Universities outputs is low and the rating of these Universities outputs were insignificantly different with respects to their sex, type of organization where they work (public or private) and their educational qualification. This therefore means that regardless of the demographics of the respondents, the employability of Nigerian Universities Outputs is low.

This result is so because graduate employability which is a measure of skills, knowledge acquired is based on their ability, quality of instruction and type of curriculum rather sex, type of organisation or academic qualifcations. This finding corroborates with the study by Dabalem, Oni \& Adekoya (2000) who found that the Nigerian employability of Nigerian graduates is outrightly poor. The insignificant difference found in the rating of the employability of these Universities outpoint with respect to the demographics of the employers agree with that of the other similar studies (Oyeneye, 2006, Mafiana, Olarunde \& Shaibu, 2005).

\section{Conclusion}

The study has provided evidence on the employability of Nigerian Universities outputs based on the views of the employers of labour in South-South, Nigeria. This study revealed that Nigerian universities outputs are not employable. This conclusion arrived at is indifferent in spite of difference in sex, organization type, educational qualification and age of the respondents. It therefore means that there is still so much to be done by the government to restructure the curriculum of the Universities in Nigeria to reflect the present reality. If this is done with the right machineries in place will reduce the high rate of unemployment in the nation.

\section{Recommendation}

In line with the findings of this study the following are recommended to enhance the employability of Nigerian Universities output in the labour markets in South-South, Nigeria.

1. Management of Universities education in Nigeria should collaborate with employers of labour in designing curriculum for courses to meet the reality of the modern labour market.

2. Internship and work study should be part of universities students' educational experience.

3. The management of various Universities in Nigeria should endavour to develop the psychomotor of the students in the area of development of practical skills that will enable them function optimally in to labour market.

4. The quality of industrial training and other programmes geared at equipping the students with practical skill should be improved upon by the government and other players in the Nigerian Universities administration.

5. A more robust and proactive measures should be taken by the government to salvage the deteriorating standard of Nigerian Universities education.

6. There is also a need for training and retraining of lecturers all Universities institution in Nigeria on modern way of teaching that will avoid students the opportunity of acquiring knowledge and skills needed in the labour market.

7. Entrepreneurial village should also establish in every institution in Nigeria so as to equip students with skills that will enable them to be self-reliant, without necessarily waiting for unavailable "white Kola" Jobs.

\section{References}

[1] Brown P, Hesketh A (2004). The Mismanagement of Talent: Employability and Jobs in the Knowledge Economy. Oxford: Oxford University Press.

[2] Dabalem A, Oni, A.s, \& Adekoya (2000). Labour Market Prospect of University Graduates in Nigeria World Bank Washington D.C.

[3] Ifinedo, P. \& Ololube, N. P. (2007a). A Discourse on the Problems, Prospects, and Progress of Distance Education in a Developing Country. In E. P. Bailey, (Ed).Focus on Distance Education Developments. Nova Science Publishers. 183-194.

[4] Imeokpana, P. O. 7 Ediagbonya, K (2012). Employability of Business Education Graduates Educational Research, 3(8): 645651.

[5] Mafiana, C.F, Olanide E., Adesina, A., A. Shanty (2005) Arts in Okebulola P., Adedipe N.O. and Urah Labour Market Expectation of Nigeria Graduates, Heinemann Education Books Nig. Plc., Ibadan.

[6] Olaleye FO (2010). Entrepreneurship Education in Tertiary Institutions in Nigeria, Implication for Millennium Development Goals (MDGs). J. Education and Leadership Development, 2, 2933. 
[7] Olofintoye, T. T. \& Prince, A. A. (2013). Employability of graduates of private tertiary institutions into Nigeria public services, perception of Nigerian parents in Ekiti State. Global Research Advanced Research Journal of Arts and humanities 2(4):79-83.

[8] Ololube, N. P. \& Egbezor, D. E. (2008). Educational technology and flexible education in Nigeria: Meeting the need for effective teacher education. In S. Marshal, W. Kinthia \& W. Taylor (Eds), Bridging the Knowledge Divide: Educational technology for development Charlotte, NC: Information Age Publishing.

[9] Ololube, N. P. (2006). Teacher Education, School Effectiveness and Improvement: A Study of Academic and Professional Qualification on Teachers' Job Effectiveness in Nigerian Secondary Schools. Doctoral Dissertation, December 2006. University of Helsinki, Faculty of Behavioural Sciences,
Department of Applied Sciences of Education. Helsinki: University of Helsinki Press.

[10] Ololube, N. P., Egbezor, D. E., \& Kpolovie, P. J. (2008). Education Policies and Teacher Education Programs: Meeting the Millennium Development Goals. Journal of Teacher Education for Sustainability, 9(1), 21-34.

[11] Overtoom, C. (2000). Employability skills: An update. ERIC Digest 220.

[12] Oyeneye, O. (2006) Current Issues in the Administration of University Education in Nigeria. Lecture delivered at the 5th Convocation Ceremony of the University of Ado-kiti, on March, 29.

[13] Swanson, R. A., Holton, E. F (2001). Foundations of Human Resource Development. San Franciso: Berrett-Koehler. 